University of Nebraska - Lincoln

DigitalCommons@University of Nebraska - Lincoln

Faculty Papers and Publications in Animal

Science

Animal Science Department

1988

Relationships Among Calcium-Dependent Protease, Cathepsins B and $\mathrm{H}$, Meat Tenderness and the Response of Muscle to Aging

Chris R. Calkins

University of Nebraska-Lincoln, ccalkins1@unl.edu

S. C. Seideman

Bryan Foods, West Point, MS

Follow this and additional works at: https://digitalcommons.unl.edu/animalscifacpub

Part of the Animal Sciences Commons

Calkins, Chris R. and Seideman, S. C., "Relationships Among Calcium-Dependent Protease, Cathepsins B and $\mathrm{H}$, Meat Tenderness and the Response of Muscle to Aging" (1988). Faculty Papers and Publications in Animal Science. 565.

https://digitalcommons.unl.edu/animalscifacpub/565

This Article is brought to you for free and open access by the Animal Science Department at DigitalCommons@University of Nebraska - Lincoln. It has been accepted for inclusion in Faculty Papers and Publications in Animal Science by an authorized administrator of DigitalCommons@University of Nebraska - Lincoln. 


\title{
RELATIONSHIPS AMONG CALCIUM-DEPENDENT PROTEASE, CATHEPSINS B AND $H$, MEAT TENDERNESS AND THE RESPONSE OF MUSCLE TO AGING ${ }^{1,2}$
}

\author{
C. R. Calkins ${ }^{3}$ and S. C. Seideman ${ }^{4}$
}

University of Nebraska, Lincoln 68583-0908

\begin{abstract}
This study was conducted to compare the relative importance of Ca-dependent protease (CDP) and cathepsins $B$ and $H$ to meat tenderness and changes in tenderness in response to postmortem cooler aging. Charolais bulls $(n=8)$ and steers $(n=7)$ were slaughtered at 15 mo of age, and total activities of CDP-I (a protease with neutral $\mathrm{pH}$ optimum that requires micromolar amounts of $\mathrm{Ca}$ for activity) and cathepsins $\mathrm{B}$ and $\mathrm{H}$ (lysosomal proteases with acidic $\mathrm{pH}$ optima) were determined within $1 \mathrm{~h}$. Shear-force values were obtained after 1, 3, 6, 9 and $14 \mathrm{~d}$ of aging. Data were pooled when analysis of variance revealed no differences between bulls and steers. Initial shear force was correlated $(\mathrm{r}=-.71, P<.10, \mathrm{n}=7$ ) to CDP-I activity (only seven animals sampled for CDP-I), and the overall change in shear force ( $\mathrm{d} 1$ to $\mathrm{d} 14$ ) was correlated to cathepsin $\mathrm{B}(\mathrm{r}=.59, P<.05, \mathrm{n}=$ $15)$. Most of the aging response occurred between $d 3$ and $d 6(41.6 \%)$, and changes in shear force during this period were related to total activities of cathepsins $B$ and $H(r=.44, .64$, respectively, $P$ $<.05$ ). Collectively, cathepsins $B$ and $H$ accounted for 35 and $58 \%$ of the variation in shear force change between $d 1$ to $d 14$ and $d 3$ to $d 6$, respectively. These data suggest that CDP-I helps to establish initial ( $d$ ) meat tenderness but that cathepsins $B$ and $H$ are responsible for the tenderization that occurs during aging. By manipulating live animal growth and postmortem handling, it might be possible to control meat tenderness through the actions of these enzyme systems.

(Key Words: Proteases, Cathepsins, Tenderness, Meat Quality.)
\end{abstract}

\section{Introduction}

One of the most critical factors influencing consumer reaction to meat is the degree of tenderness. In general, most meat is more tender after a 7 to $10 \mathrm{~d}$ postmortem aging period than it is the day after slaughter (Smith et al., 1978). This response to aging provides one mechanism that aids in overcoming problems associated with muscle that is less tender. The response of muscles to aging is quite variable among animals and among muscles from the same animals. Understanding the aging process would increase our ability to deal with meat of undesirable tenderness.

There are several protease systems within muscle that could contribute to tenderness. The Ca-dependent proteases (CDP) require $\mathrm{Ca}$ and

\footnotetext{
${ }^{1}$ Journal Series No. 8392, Agric. Res. Div., Univ. of Nebraska.

${ }^{2}$ The authors wish to acknowledge M. Koohmaraie of the Roman L. Hruska U.S. Meat Anim. Res. Center, Clay Center, NE for providing the CDP enzyme data.

${ }^{3}$ Dept. of Anim. Sci. 39773.

${ }^{4}$ Currently with Bryan Foods, West Point, MS

Received June 29, 1987.

Accepted December 7, 1987.
}

have a neutral $\mathrm{pH}$ optimum for activity. The calcium is made available during rigor mortis by its release from the sarcoplasmic reticulum. The lysosomal enzymes (primarily cathepsins) also may influence tenderness. These enzymes have acidic $\mathrm{pH}$ optima for activity. There has been disagreement about which of these systems is most important in determining the ultimate tenderness of meat (Marsh, 1983). The CDP system has been shown to have specific action on a variety of muscle proteins (Olson et al., 1977; Koohmaraie et al., 1986) and could function early postmortem when the $\mathrm{pH}$ is still high. By comparison, the cathepsins also have some activity toward muscle proteins but could function best when the $\mathrm{pH}$ has dropped closer to their optima for activity (Dutson and Lawrie, 1974).

Understanding the relative impact of these two enzyme systems on meat tenderness could lead to a variety of benefits. Postmortem handling procedures could be identified to optimize the activity of the appropriate system. Perhaps animals with a propensity to synthesize and activate the appropriate enzyme system could be identified and used selectively for production of especially tender meat. Manipulation of live animal growth may influence these 
systems; therefore, unique production practices might be identified to exert positive influences on the genetic potential for postmortem proteolysis.

This study was conducted to compare the relative importance of the CDP and catheptic enzyme systems to meat tenderness and the response of muscle to aging.

\section{Materials and Methods}

Charolais bulls $(n=8)$ and steers $(n=7)$ were slaughtered at 15 mo of age. Following a 24-h chill $\left(-1\right.$ to $\left.1^{\circ} \mathrm{C}\right)$, the carcasses were moved to a holding cooler $\left(2\right.$ to $5^{\circ} \mathrm{C}$ ) for the remainder of the study.

The Ca-dependent proteases (CDP-I, which requires micromolar $\mathrm{Ca}$ for activity, and CDPII, which requires millimolar amounts of $\mathrm{Ca}$ ) and their inhibitor activities were determined on longissimus muscle samples obtained from four bull and three steer carcasses within $1 \mathrm{~h}$ of slaughter. Cross-sections of the entire muscle were removed from the region of the third lumbar vertebrae. About $250 \mathrm{~g}$ were removed, from which $10 \mathrm{~g}$ were dedicated to determination of lysosomal protease activity. Cathepsin $B$, cathepsin $\mathrm{H}$ and $\beta$-glucuronidase were determined on muscle samples obtained from all carcasses within $1 \mathrm{~h}$ of slaughter. The latter enzyme was assayed because it is commonly used as an indicator of lysosomal protease location and activity.

The CDP enzyme and inhibitor activities were determined by the methods of Koohmaraie et al. (1987). Briefly, $200 \mathrm{~g}$ of muscle were frozen in liquid $\mathrm{N}$ and thawed for assay at $2^{\circ} \mathrm{C}$ for $90 \mathrm{~min}$. Samples were homogenized in a Waring blender in 2.5 volumes of $10 \mathrm{mM}$ tris- $\mathrm{HCl}$, pH 7.5, containing $4 \mathrm{mM}$ ethylenediametetraacetate (EDTA), $50 \mathrm{~m} M \quad \mathrm{NaCl}$ and $2 \mathrm{mM}$ mercaptoethanol (MCE). After $1 \mathrm{~h}$ of gentle mixing, the homogenate was centrifuged at $30,000 \times g$ for $50 \mathrm{~min}$. The supernatant fluid was filtered through two layers of cheesecloth, and the $\mathrm{pH}$ was adjusted to 7.5. The supernatant fluid was chromatographed on diethylaminoethyl (DEAE)-Sephacel that had been equilibrated with an elution buffer of 5 $\mathrm{m} M$ Tris- $\mathrm{HCl}, \mathrm{pH} \mathrm{7.4}$, containing $50 \mathrm{mM} \mathrm{NaCl}$, $.1 \mathrm{~m} M$ EDTA and $2 \mathrm{~m} M$ MCE. The bound

\footnotetext{
${ }^{5}$ Instron Corp., Canton, MA.
}

proteins were eluted at the rate of $30 \mathrm{ml} / \mathrm{h}$ with a continuous, $800-\mathrm{ml}$ gradient of 50 to $500 \mathrm{mM}$ $\mathrm{NaCl}$ in elution buffer.

Activity of CDP-I was assayed according to the procedures of Koohmaraie et al. (1986) and CDP-II by the procedures of Koohmaraie et al. (1984). Incubation time was $50 \mathrm{~min}$. Activities were expressed as the amount of Ca-dependent caseinolytic activity in $200 \mathrm{~g}$ of muscle. Inhibitor activity was defined as the reduction in Ca-dependent caseinolytic activity generated by the inhibitor. Appropriate dilutions were made during quantitation of the inhibitor to reduce enzyme activity by 30 to $80 \%$. This was done to avoid errors that might occur with standard dilution volumes (Koohmaraie et al., 1987).

Cathepsins $B$ and $H$ and $\beta$-glucuronidase activities were quantiated after preparation of the sample by the methods of Moeller et al. (1976). In general, $10 \mathrm{~g}$ of finely minced tissue were homogenized in $40 \mathrm{ml}$ of $.02 \mathrm{M} \mathrm{KCl}$ containing $.25 M$ sucrose. The homogenate was centrifuged at $3,000 \times g$ for $5 \mathrm{~min}$ and resuspended in $35 \mathrm{ml}$ of $.02 \mathrm{M} \mathrm{KCl}$ containing $.25 M$ sucrose and resedimented. Aliquots (30 $\mathrm{ml}$ ) of the pooled supernatant fractions were ultracentrifuged at $102,000 \times g$ for $2 \mathrm{~h}$. The resulting pellets and supernatants were used to determine the amounts of bound and unbound proteolytic enzymes, respectively.

Total activities of cathepsin B and cathepsin $\mathrm{H}$ were determined by the techniques of Barrett (1980) using amino-methyl coumarin as a fluorescent tag on the substrate. Activities of these enzymes were expressed as the total amount of enzyme in $10 \mathrm{~g}$ of muscle capable of hydrolyzing the specific substrate. Total activity of $\beta$-glucuronidase was the amount of enzyme in $10 \mathrm{~g}$ of muscle capable of hydrolyzing an enzyme-specific substrate containing methylumbelliferone (Moeller et al., 1976).

Carcass data for this population will be presented in a paper by Seideman et al. (1988).

Loin steaks (3 cm thick) were removed posterior to the 13 th rib and frozen at $-10^{\circ} \mathrm{C}$. Steaks from the left side of the carcasses were removed after 1 and $3 \mathrm{~d}$ of aging and from the right side of the carcasses after 6,9 , and $14 \mathrm{~d}$ of aging. Thawed steaks $\left(24 \mathrm{~h}\right.$ at $\left.1^{\circ} \mathrm{C}\right)$ were cooked to $70^{\circ} \mathrm{C}$ for assessment of shear-force value using a Warner-Bratzler shear attachment to an Instron Universal Testing Machine ${ }^{5}$. Steaks (except for d 9) were cooked for evaluation by a 10 -member, trained and tested (Cross 
et al., 1978) descriptive attribute panel for ease of fragmentation and overall tenderness (8-point rating scales: 1 = extremely difficult or extremely tough; $8=$ extremely easy or extremely tender, respectively).

The data were analyzed by correlation, regression and analysis of variance (Steel and Torrie, 1980).

\section{Results}

Analysis of variance did not reveal any differences between bulls and steers in this study for any of the traits discussed. This may be a consequence of low numbers and a variable population. All remaining analyses were conducted on the pooled population.

Figure 1 displays the decline in shear-force value that occurred during aging from $d 1$ to $d$ 14. Between $d 1$ and $d 3$ of aging, $39.5 \%$ of the overall reduction in shear force occurred. An additional $41.6 \%$ of the total change took place between $d 3$ and $d 6$. Shear force was reduced by only $4.0 \%$ of the total between $\mathrm{d} 6$ and $\mathrm{d} 9$, whereas $14.9 \%$ of the total change occurred during the last aging period ( $\mathrm{d} 9$ to $\mathrm{d}$ 14). These data indicate that most of the response to aging in muscle, as measured by shear force, occurs during the first $6 \mathrm{~d}$ postmortem. These data are in agreement with data published by Martin et al. (1971). Changes in sensory evaluation ratings for tenderness and ease of fragmentation were not so dramatic (Figure 1).

The initial shear force at $d 1$ was variable (from 5.99 to $11.2 \mathrm{~kg}$, coefficient of variation

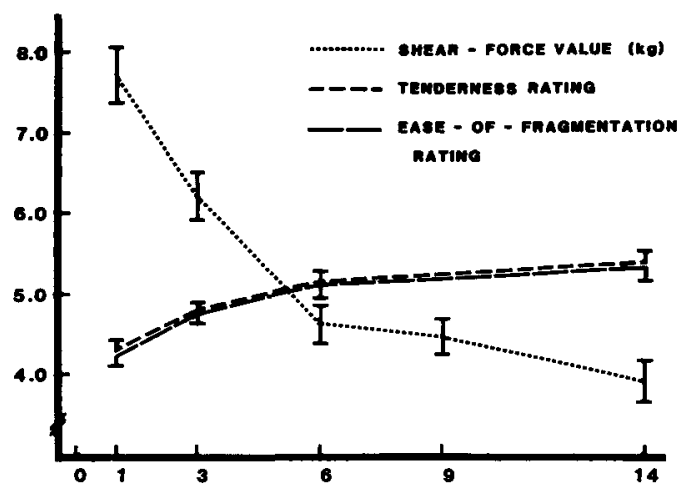

Figure 1. Changes in shear-force values and ease-offragmentation and tenderness ratings during cooler aging of beef muscle.

$17.4 \%$ ), as was the overall change in shear force in response to aging (from 1.50 to $6.35 \mathrm{~kg}$, coefficient of variation $=36.3 \%$ ). Thus, this sample population exhibited sufficient variation in tenderness characteristics to be quite valuable in the investigation of the relative impact of proteolytic enzymes.

Table 1 presents the apparent specific activities and total activities of the proteolytic enzymes evaluated in this study. The term "apparent" is used here to denote that enzymes were not isolated; this is the activity found per milligram of protein in the muscle homogenate. These values are consistent with other data

TABLE 1. MEANS AND STANDARD ERRORS FOR APPARENT SPECIFIC ACTIVITIES AND TOTAL ACTIVITIES OF PROTEOLYTIC ENZYMES

\begin{tabular}{|c|c|c|c|c|}
\hline \multirow[b]{2}{*}{ Enzyme } & \multicolumn{2}{|c|}{ Apparent specific activity } & \multicolumn{2}{|c|}{ Total activity } \\
\hline & Mean & $\mathrm{SE}$ & Mean & SE \\
\hline Cathepsin $\mathrm{B}^{\mathrm{a}}$ & 33.27 & 3.11 & 15.98 & 1.26 \\
\hline Cathepsin $\mathbf{H}^{\mathrm{a}}$ & 84.18 & 8.33 & 59.21 & 6.71 \\
\hline$\beta$-glucuronidase $\mathrm{e}^{\mathrm{a}}$ & 17.53 & .99 & 8.79 & .70 \\
\hline CDP-Ib & $\mathrm{NA}^{\mathrm{d}}$ & & 65.90 & 6.25 \\
\hline CDP-II ${ }^{b}$ & NA & & 8663 & 2.04 \\
\hline CDP-Inhibitorc & NA & & 123.40 & 5.52 \\
\hline
\end{tabular}

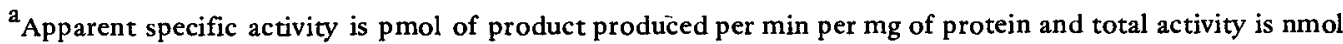
of product produced per min per total protein in $10 \mathrm{~g}$ of muscle.

${ }^{\mathrm{b}} \mathrm{CDP}=$ calcium-dependent protease. Total activity is low $\mathrm{Ca}^{++}(\mathrm{CDP}-\mathrm{I})$ or high $\mathrm{Ca}^{++}(\mathrm{CDP}-\mathrm{II})$-dependent casienolytic activity $\left(A_{278}\right)$ per $200 \mathrm{~g}$ of muscle.

c Amount of CDP-II caseinolytic activity $\left(A_{278}\right)$ inhibition in $200 \mathrm{~g}$ of muscle.

$\mathrm{d}_{\mathrm{NA}}=$ not assessed.
} 
from our laboratory and the results of Koohmaraie et al. (1987).

Simple correlation coefficients between total enzyme activities and selected tenderness measurements are presented in Table 2 . The micromolar Ca-dependent form of the enzyme CDP-I is most active at neutral $\mathrm{pH}$ and thus would be expected to have an impact on the tenderness characteristics of the muscle. Because CDP-II requires a millimolar amount of $\mathrm{Ca}$ for activity, not a physiological condition within muscle, it would not be expected to influence tenderness. Thus, the data for CDP-II are not discussed. Activity of CDP-I was related to d-1 shear force $(P<.10)$. Samples with higher activities of the enzyme had lower shear forces. This suggests that CDP-I may be active between the time of slaughter and $d$. The lower correlation between CDP-I activity and d-3 shear is probably a reflection of reduced CDP$I$ activity and suggests that other enzymes besides CDP-I are working between $\mathrm{d} 1$ and $\mathrm{d} 3$. Koohmaraie et al. (1987) have demonstrated that the activity of CDP-I drops about $50 \%$ by $\mathrm{d} 1$. The cathepsins would be anticipated to continue proteolysis because an acidic $\mathrm{pH}$ closer to their optima would be attained by $d 1$. It is difficult to rationalize why cathpsin B activity possesses a positive correlation to $d-1$ and $d-3$ shear. The negative correlation between cathepsin $\mathrm{H}$ activity and $\mathrm{d}-3$ shear is consistent with the notion that elevated activities of cathepsins are partly responsible for lowering shear forces during the aging process. In an attempt to determine which enzymes are involved with the aging process from $d 1$ to $d$ 14 , the changes in shear force over time were examined (Table 2). Cathepsin B activity was significantly related to the overall ( 1 to $d 14$ ) change in shear force $(\mathrm{r}=.59)$ and exhibited a strong $(P<.10)$ correlation $(r=.44)$ with the change with aging from $d 3$ to $d 6$. Similarly, cathepsin $\mathrm{H}$ activity was highly related to the change with aging from $d 3$ to $d 6(r=.64 ; P<$ $.05)$. These data indicate the importance of the cathepsins to aging. Correlations between CDP-I activity and aging were not significant except for $d 9$ to $d 14$. This latter relationship likely is not cause-and-effect, because CDP-I has little activity under these conditions. The

TABLE 2. CORRELATION COEFFICIENTS AMONG TOTAL ACTIVITY OF CATHEPSIN B, CATHEPSIN H, $\beta$-GLUCURONIDASE, Ca-DEPENDENT PROTEASE-I AND -II AND SELECTED TENDERNESS MEASURES

\begin{tabular}{|c|c|c|c|c|c|}
\hline \multirow[b]{2}{*}{ Muscle trait } & \multicolumn{5}{|c|}{ Enzyme traits } \\
\hline & Cathepsin B & Cathepsin $\mathrm{H}$ & $\beta$-glucuronidase & CDP-I & CDP-II \\
\hline \multicolumn{6}{|l|}{ Shear force } \\
\hline D 1 & $.63^{* *}$ & -.07 & .09 & $-.71 *$ & $-.70^{*}$ \\
\hline D 3 & $.61 * *$ & .09 & .30 & -.35 & -.20 \\
\hline D 6 & .24 & $-.57 * *$ & .05 & -.45 & -.07 \\
\hline D 9 & .18 & .02 & .20 & -.14 & .17 \\
\hline D 14 & .02 & -.16 & .29 & -.69 & -.19 \\
\hline \multicolumn{6}{|c|}{ Change in shear force } \\
\hline D $1-d 14$ & $.59 * *$ & .06 & -.14 & .10 & -.47 \\
\hline D $1-d 3$ & .13 & -.21 & -.25 & -.50 & $-.68^{*}$ \\
\hline D 3-d 6 & $.44^{*}$ & $.64 * * *$ & .28 & -.07 & -.24 \\
\hline D $6-d 9$ & .10 & $-.71 * * *$ & -.15 & -.38 & -.36 \\
\hline D 9-d 14 & .15 & .22 & -.15 & $.75^{*}$ & .38 \\
\hline \multicolumn{6}{|c|}{ Ease of fragmentation rating } \\
\hline D 1 & $-.47^{*}$ & .25 & .06 & .62 & .58 \\
\hline D 14 & .07 & -.09 & $.46^{*}$ & .41 & .24 \\
\hline D $1-\mathrm{d} 14$ & -.35 & -.24 & -.19 & .07 & .31 \\
\hline \multicolumn{6}{|c|}{ Overall tenderness rating } \\
\hline D 1 & -.36 & .17 & -.07 & .54 & .45 \\
\hline D 14 & -.01 & .43 & .22 & .41 & .22 \\
\hline D $1-d 14$ & $.63 * *$ & -.07 & .09 & -.02 & .18 \\
\hline
\end{tabular}

${ }^{*} P<.10$.

$* * P<.05$.

$* * P<.01$ 
significant, negative correlation between cathepsin $\mathrm{H}$ activity and the change in shear force from d 6 to $d 9$ is probably of little value because only $4.0 \%$ of the change in shear force occurred during this time frame.

The relationships between any of the enzyme activities and taste panel ratings for ease of fragmentation and overall tenderness were generally of a lower magnitude. However, the correlation between cathepsin $B$ and overall ( $d$ 1 to $d$ 14) response to aging for overall tenderness rating $(\mathrm{r}=.63, P<.05)$ was still evident (Table 2).

It is apparent that activities of both cathepsins $B$ and $H$ possess significant correlations with the response of muscle to aging. It is not clear, however, if these correlations are independent or if the two are accounting for the same variation and, thus, are interrelated. Regression equations were created that contained as independent variables the total activities of cathepsins $B$ and $\mathrm{H}$ and their interaction, a term used to indicate the degree of dependence between the enzymes. In every case, the interaction term was not significant, indicating that these enzymes account for different variation in the aging response. To more accurately depict the influence of cathepsin $\mathrm{B}$ and $\mathrm{H}$ activities, regression equations were regenerated without the interaction term (Table 3 ). The limited number of CDP-I samples prevented their meaningful analyses.

The data in Table 3 highlight the collective impact of cathepsin $B$ and $\mathrm{H}$ activities on shear force at $\mathrm{d} 3$ and $\mathrm{d} 6$. Additionally, the change in shear force between $d 3$ and $d 6$ and between d 6 and $d 9$ appears strongly related to these enzymes. The low coefficient of determination for these enzymes and the change in shear force between $d 1$ and $d 3$ once again suggests that several enzyme systems are likely at work, thereby decreasing the strength of the relationship to individual enzyme systems.

\section{Discussion}

The initial (d 1) shear force of longissimus muscle appears to be related to CDP-I activity. The overall response to aging, however, is strongly related to cathespin $\mathrm{B}$ and $\mathrm{H}$ activity. This seems consistent with the characteristics of these enzyme systems. The CDP-I enzyme is active within the first $24 \mathrm{~h}$, and perhaps beyond, when the $\mathrm{pH}$ most closely parallels its $\mathrm{pH}$ optimum. The cathepsins increase in importance when conditions favor their activity and suppress the activity of other enzymes. Dutson (1983) and Lee (1986) proposed a similar relationship based on a review of the literature.

There are several implications of these results. Savell et al. (1981) wrote about the meat that was inherently tough (requiring postmortem aging to enhance tenderness) or inherently tender (not requiring aging to become tender). Perhaps this level of inherent tenderness is defined by the amount and(or) activity of CDP-I within the living muscle. If so, it may be possible to control tenderness through manipulation of animal growth. It is well known that increases in growth rate reflect

TABLE 3. REGRESSION ANALYSES RELATING TOTAL ACTIVITIES OF CATHEPSINS B AND H TO SELECTED SHEAR-FORCE MEASURES

\begin{tabular}{lcc} 
Dependent variable & Probability of $>F$ \\
\hline Shear force & Coefficient of determination & .04 \\
D 1 & 40.43 & .06 \\
D 3 & 38.17 & .05 \\
D 6 & 39.76 & .82 \\
D 9 & 3.16 & .85 \\
D 14 & 2.65 & .07 \\
Change in shear force & & .67 \\
D 1-d 14 & 35.45 & .01 \\
D 1-d 3 & 6.35 & .01 \\
D 3-d 6 & 57.99 & .65 \\
D 6-d 9 & 51.57 & .67 \\
D 9-d 14 & 6.84 & \\
\hline
\end{tabular}

\footnotetext{
${ }^{\mathrm{a}}$ Independent variables were total activities of cathepsins B and $\mathrm{H}$.
} 
increases in rate of protein accretion. This net increase occurs by an elevation of the rate of prorein synthesis and a concomitant, but lesser, elevation of protein degradation (Millward et al., 1975; Millward and Waterlow, 1978). Because CDP (Dayton et al., 1981) and cathepsins are related to protein turnover in the living animal, animals that are slaughtered during periods of rapid growth might exhibit enhanced muscle proteolysis and thus provide more tender meat. Aberle et al. (1981) suggested such a phenomenon when they noted that rate of growth at slaughter was related to tenderness. Others subsequently were able to demonstrate a similar relationship between growth rate and tenderness (Hall and Hunt, 1982; Fishell et al., 1985 ), although the causes of enhanced tenderness were not conclusively demonstrated. Wu et al. (1981) believed that rapid synthesis and degradation of collagen resulted in immature collagen, which is more heat-soluble and therefore more tender. The concept of manipulation of growth rate as a way to alter catheptic enzyme profile served as the basis for a study by Calkins et al. (1987), but we were unable to document changes in cathepsins in young bulls. In this latter study, rate of growth was unrelated to tenderness (Crouse et al., 1986), but a relationship between cathepsin activities and meat tenderness was noted. Apparently, there are several factors that influence the effect of growth rate on tenderness that have yet to be considered.

Other aspects of the literature also might be explained by the results of this study. Locker and Daines (1975), Davey and Gilbert (1976), Lochner et al. (1980) and Marsh (1983) all have concluded that the muscle temperature profile very early postmortem plays a major role in meat tenderness. Marsh (1983) also noted that, within specified temperature ranges, those carcasses with lower muscle $\mathrm{pH}$ were less tender. Khan and Lentz (1973) reported a positive relationship between tenderness and muscle $\mathrm{pH}$. This can be explained on the basis of CDP-I activity. Higher temperatures, to a degree, promote enzyme activity, and those muscles with higher $\mathrm{pH}$ at a given temperature would be most conducive to CDP-I action during the first $24 \mathrm{~h}$ postmortem. Based on the data presented here, higher muscle temperature and $\mathrm{pH}$ would be expected to enhance initial (d 1) tenderness of carcasses.

Research also exists that suggests that lowered $\mathrm{pH}$, when coupled with high muscle temperature (as in electrically stimulated beef), promotes tenderization (Dutson et al., 1980). Such conditions, although antagonistic of CDP-I action, would be conducive to cathepsin activity. From the data reported here, a more rapid response to aging would be anticipated. In fact, Savell et al. (1981) found that electrically stimulated carcasses were equal in tenderness, 1 d postmortem to paired, unstimulated sides that had been aged up to $11 \mathrm{~d}$ postmortem; this suggests that aging rate was accelerated. Part of this also may have been due to structural damage (Savell et al., 1978).

An analogous situation probably existed during the high-temperature, post-rigor conditioning work by Sleeth et al. $(1957,1958)$ and by Wilson et al. (1960). In their experiments, muscle temperature was elevated after rigor was complete. This would have created the high-temperature, low-pH condition conducive to catheptic action, which could account for the considerable improvement in tenderness that was achieved.

In the Savell et al. (1981) study, unstimulated carcasses from grain-fed cattle ultimately reached the same general level of tenderness (about $4 \mathrm{~kg} / 1.27-\mathrm{cm}$ core) as electrically stimulated carcasses. The ultimate level of tenderness also was about $4 \mathrm{~kg} / 1.27-\mathrm{cm}$ core in our study. Others have noted also that prolonged cooler aging beyond about $14 \mathrm{~d}$ does not enhance tenderness (Larmond et al., 1969; Martin et al., 1971; Davis et al., 1975). This suggests that a limit exists beyond which endogenous proteolytic enzymes cannot improve meat tenderness. The background level of tenderness might be established by the characteristics of the connective tissue. Perhaps the mode of proteolysis (through either the CDP system or the cathepsin system) does not differ in its ultimate effect on meat tenderness, only in the rate at which maximum tenderization is reached. This, in turn, is partly a function of temperature, $\mathrm{pH}$ and aging time. This contrasts with the marked differences in the mode of action for these enzymes (Dutson, 1983 ; Koohmaraie et al., 1986).

The results of the present study suggest that two enzyme systems are involved in postmortem tenderization of meat:the CDP system, which has neutral pH optima, and the cathepsin (lysosomal) system, which has acidic $\mathrm{pH}$ optima. Depending on manipulation of live animal growth and postmortem handling procedures, 
the ultimate level of meat tenderness might be controlled through the actions of these enzyme systems.

\section{Literature Cited}

Aberle, E. D., E. S. Reeves, M. D. Judge, R. E. Hunsley and T. W. Perry. 1981. Palatability and muscle characteristics of cattle with controlled weight gain: Time on a high energy diet. J. Anjm. Sci. 52:757.

Barrett, A. J. 1980. Fluorimetric assays for cathepsin $B$ and cathepsin $H$ with methylcoumarylamide substrates. Biochem. J. 187:909.

Calkins, C. R., S. C. Seideman and J. D. Crouse, 1987. Relationships between rate of growth, catheptic enzymes and meat palatability in young bulls. J. Anim. Sci. 64:1448.

Cross, H. R., R. Moen and M. S. Stanfield. 1978. Training and testing of judges for sensory analysis of meat quality. Food Technol. $32(7): 48$.

Crouse, J. D., C. R. Calkins and S. C. Seideman. 1986. The effect of rate of change in body weight on tissue development and meat quality of youthful bulls. J. Anim. Sci. 63:1824.

Davey, C. L. and K. V. Gilbert. 1976. The temperature coefficient of beef aging. J. Sci. Food Agric. 27:244.

Davis, K. A., D. L. Huffman and J. C. Cordray. 1975. Effect of mechanical tenderization, aging and pressing on beef quality. J. Food Sci. 40:1222.

Dayton, W. R., J. E. Schollmeyer, R. A. Leply and L. R. Cortes. 1981. A calcium-activated protease possibly involved in myofibrillar protein turnover. Isolation of a low-calcium-requiring form of the protease. Bjochim. Biophys. Acta 659:48.

Dutson, T. R. 1983. Relationship of $\mathrm{pH}$ and temperature to disruption of specific muscle proteins and activity of lysosomal proteases. J. Food Biochem. $7: 223$.

Dutson, T. R. and R. A. Lawrie. 1974. Release of lysosomal enzymes during postmortem conditioning and their relationship to tenderness. J. Food Technol. 9:43.

Dutson, T. R., G. C. Smith, J. W. Savell and Z. L. Carpenter. 1980. Possible mechanisms by which electrical stimulation improves meat tenderness. Proc. 26th Eur. Mtg. Meat Res. Workers 2:84.

Fishell, V. K., E. D. Aberle, M. D. Judge and T. W. Perry. 1985. Palatability and muscle properties of beef as influenced by preslaughter growth rate. J. Anim. Sci. 61:151.

Hall, J. B. and M. C. Hunt. 1982. Collagen solubility of A-maturity bovine longissimus muscle as affected by nutritional regimen. J. Anim. Sci. $55: 321$.

Khan, A. W. and C. P. Lentz. 1973. Influence of ante-mortem glycolysis and dephosphorylation of high energy phosphates on beef aging and tenderness. J. Food Sci. 38:56.

Koohmaraie, M., W. H. Kennick, E. A. Elgasim and A. F. Anglemier. 1984. Effect of pre-rigor pressurization on the activity of calcium-activated factor. J. Food Sci. 49:680.

Koohmaraie, M., J. E. Schollmeyer and T. R. Dutson. 1986. Effect of low-calcium-requiring activated factor of myofibrils under varying $\mathrm{pH}$ and temperature conditions. J. Food Sci. 51:28.

Koohmaraie, M., S. C. Seideman, J. E. Schollmeyer, T. R. Dutson and J. D. Crouse. 1987. Effect of postmortem storage on $\mathrm{Ca}^{++}$-dependent proteases, their inhibitor and myofibril fragmentation. Meat Sci. 19:187.

Larmond, E., A. Petrasovits and P. Hill. 1969. Appljcation of multiple paired comparison in studying the effects of aging and finish on beef tenderness. Can. J. Anim. Sci. 49:51.

Lee, Y. B. 1986. Early postmortem measurements and conditioning in assessing and enhancing meat quality. J. Anim. Sci. 63:622.

Locker, R. H. and G. J. Daines. 1975. Tenderness in relation to the temperature of rigor onset in cold shortened beef. J. Sci. Food Agric. 2 7:193.

Lochner, J. V., R. G. Kauffman and B. B. Marsh. 1980. Early-postmortem cooling rate and beef tenderness. Meat Sci. 4:227.

Marsh, B. B. 1983. Effect of early-postmortem muscle $\mathrm{pH}$ and temperature on meat tenderness. Proc. Recip. Meat Conf. 36:131.

Martin, A. H., T. Fredeen and G. M. Weiss. 1971. Tenderness of beef longissimus dorsi muscle from steers, heifers and bulls as influenced by source, postmortem aging and carcass characteristics. J. Food Sci. 36:619.

Millward, D. J., P. J. Garlick, R.J.C. Stewart, D. O. Nnanyelugo and J. C. Waterlow. 1975. Skeletal muscle growth and protein turnover. Biochem. J. $150: 235$.

Millward, D. J. and J. C. Waterlow. 1978. Effect of nutrition of protein turnover in skeletal muscle. Fed. Proc. 3 7:2283.

Moeller, P. W., P. A. Fields, T. R. Dutson, W. A. Landmann and Z. L. Carpenter. 1976. Effect of high temperature conditioning on subcellular distribution and levels of lysosomal enzymes. J. Food Sci. $41: 216$.

Olson, D. G., E. C. Parrish, Jr., W. R. Dayton and D. E. Goll. 1977. Effect of postmortem storage and calcium activated factor on the myofibrillar proteins of bovine skeletal muscle. J. Food Sci. $42: 117$.

Savell, J. W., T. R. Dutson, G. C. Smith and Z. L. Carpenter. 1978. Structural changes in electrically stimulated beef muscle. J. Food Sci. 43:1606.

Savell, J. W., F. K. McKeith and G. C. Smith. 1981. Reducing postmortem aging time of beef with electrical stimulation. J. Food Sci. 46:1777.

Seideman, S. C., M. Koohmaraie and J. D. Crouse. 1988. Factors associated with tenderness of meat from bulls and steers. Meat Sci. (In press).

Sleeth, R. B., R. L. Henrickson and D. E. Brady. 1957. Effect of controlling environmental conditions during aging on the quality of beef. Food Technol. 11:205.

Sleeth, R. B., G. G. Kelley and D. E. Brady. 1958. Shrinkage and organoleptic characteristics of beef aged in controlled environments. Food Technol. 12:86.

Smith, C. G., G. R. Culp and Z. L. Carpenter. 1978. Postmortem aging of beef carcasses. J. Food Sci. $43: 823$. 
Steel, R.G.D. and J. H. Torrie. 1980. Principles and Procedures of Statistics (2nd Ed.). McGraw-Hill Book Co., New York.

Wilson, G. D., P. D. Brown, W. R. Chesbro, B. Ginger and C. E. Weir. 1960. The use of antibiotics and gamma irradiation in the aging of steaks at high temperatures. Food Technol. 14:143.

Wu, J. J., C. L. Kastner, M. C. Hunt, D. H. Kropf and D. M. Allen. 1981. Nutritional effects on beef collagen and palatability. J. Anim. Sci. 53:1256. 